See discussions, stats, and author profiles for this publication at: https://www.researchgate.net/publication/320666981

\title{
Combating dye pollution using cocoa pod husks: a sustainable approach
}

Article in International Journal of Sustainable Engineering · October 2017

DOI: 10.1080/19397038.2017.1393023

CITATIONS

7

4 authors:

28 Moses Olakunle

Ladoke Akintola University of Technology

5 PUBLICATIONS 32 CITATIONS

SEE PROFILE

Adewumi Oluwasogo Dada

Landmark University

57 PUBLICATIONS 774 CITATIONS

SEE PROFILE
233

Adejumoke Inyinbor

Landmark University

40 PUBLICATIONS 135 CITATIONS

SEE PROFILE

Olugbenga Solomon Bello

Ladoke Akintola University of Technology, Oyo. Nigeria and University of Science ... 80 PUBLICATIONS 1,250 CITATIONS

SEE PROFILE

Some of the authors of this publication are also working on these related projects:

Pollution Control View project

Medicinal Chemistry View project 


\section{Combating dye pollution using cocoa pod husks: a sustainable approach}

\section{Moses Olabode Olakunle, Adejunmoke Abosede Inyinbor, Adewumi Oluwasogo Dada \& Olugbenga Solomon Bello}

To cite this article: Moses Olabode Olakunle, Adejunmoke Abosede Inyinbor, Adewumi Oluwasogo Dada \& Olugbenga Solomon Bello (2017): Combating dye pollution using cocoa pod husks: a sustainable approach, International Journal of Sustainable Engineering

To link to this article: http://dx.doi.org/10.1080/19397038.2017.1393023

\section{曲 Published online: 25 Oct 2017.}

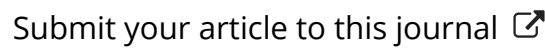

\section{Q View related articles $ᄃ$}

View Crossmark data $\nearrow$ 


\title{
Combating dye pollution using cocoa pod husks: a sustainable approach
}

\author{
Moses Olabode Olakunle ${ }^{a}$, Adejunmoke Abosede Inyinbor ${ }^{b}$, Adewumi Oluwasogo Dadab and \\ Olugbenga Solomon Bello
}

aDepartment of Pure and Applied Chemistry, Ladoke Akintola University of Technology, Ogbomoso, Nigeria; ${ }^{\mathrm{b}}$ Department of Physical Sciences, Industrial Chemistry Programme, Landmark University, Omu-Aran, Nigeria

\begin{abstract}
The adsorptive potential of activated carbon prepared by chemical activation of Cocoa pod husk (CPHAA) to remove Congo red (CR) dye from its aqueous solution was investigated in this study. CPHAA was characterised using Energy Dispersive X-Ray, Scanning Electron Micrograph and Fourier Transform Infrared Spectroscopy techniques. The effects of contact time, initial dye concentration, $\mathrm{pH}$ and solution temperature were studied. Equilibrium data were fitted to Langmuir, Freundlich, Temkin and DubininRadushkevich isotherm models. The equilibrium data were best represented by Langmuir isotherm model, with maximum monolayer adsorption capacity of $43.67 \mathrm{mg} / \mathrm{g}$. The kinetic data were fitted to Pseudofirst-order, Pseudo-second-order, Elovich and Intraparticle diffusion models; the pseudo-second-order kinetic model provided the best correlation. Thermodynamic parameters such as standard enthalpy $\left(\Delta H^{\circ}\right)$, standard entropy $\left(\Delta S^{\circ}\right)$ and standard free energy $\left(\Delta G^{\circ}\right)$ were evaluated. The thermodynamic study showed that the process is endothermic, spontaneous and feasible. The mean free energy of adsorption shows that the mechanism is by physisorption. CPHAA was found to be an effective adsorbent for the removal of CR dye from aqueous solution.
\end{abstract}

ARTICLE HISTORY

Received 19 October 2016

Accepted 26 September 2017

\section{KEYWORDS}

Cocoa pod husk; adsorption; equilibrium; kinetics; thermodynamics

\section{Introduction}

Water pollution is one of the most serious ecological threats we face today that requires urgent solution. Water bodies are contaminated by organic and inorganic substances. Inorganic compound is the heavy metals and is classified under anthropogenic and natural sources of water pollution. Organic compounds pollutants include detergent, organochlorine, organophosphorous, polycyclic aromatic compounds, aromatic compounds from petroleum and dyes. Dyes have long been used in dyeing, paper and pulp, textiles, plastics, leather, cosmetics and food industries. Textile industry uses dyes and pigments to colour their product. There are more than 100,000 commercially available dyes with over $7 \times 10^{5}$ tonnes of dyestuff are produced annually (Robinson et al. 2001; Soloman et al. 2009; Baban, Yediler, and Ciliz 2010). The main sources of wastewater generated by the textile industry originate from the washing and bleaching of natural fibres and from the dyeing and finishing steps. Given the great variety of fibres, dyes and process aids, these processes generate wastewater of great chemical complexity and diversity, which are not adequately treated in conventional wastewater treatment Plant (Wang et al. 2005). Dyes are classified into three broad categories: (1) anionic - direct, acid and reactive dyes; (2) cationic - all basic dyes; and (3) nonionic - dispersed dyes (Mishra and Tripathy 1993). Dyes usually have complex aromatic molecular structures, which make them more stable and difficult to biodegrade (Amin 2008a). Synthetic dyes, classified by their chromophores, have different and stable chemical structures to meet various colouring requirement and are not often degraded or removed by conventional physical and chemical processes. Effluents from these industries must be treated to reduce the concentration of dyes present within permissible limits before discharge into water bodies, as required by environmental regulations (Namasivayam, Radhika, and Suba 2001; Bhattacharyya and Sharma 2004; Aksu 2005). Coming to term with the menace of pollution has been a major worry for the dyers in face of increasing pressure from strict environmental laws. Dyes are moderately resistant to light and oxidation agents, thus they cannot be completely removed by the conventional methods of anaerobic digestion (Seshadri, Bishop, and Agha 1994). Methods used to treat colour effluents are coagulation and flotation (Panswed and Wongehaisuwan 1986), ozonation (Malik and Saha 2003), membrane separation (Ciardelli, Corsi, and Marucci 2000) and adsorption by activated carbon (DeoMall et al. 2005). However, the single conventional treatment is unable to remove certain forms of colour, particularly those arising from reactive dyes as a result of their high solubility and low biodegradability (Vijayaraghavan, Won, and Yun 2009). The adsorption process is an attractive alternative treatment for dye removal from wastewater and is employed mainly for its efficiency and economy (Namasivayam, Yamuna, and Jayanthi 2003; Gurses et al. 2006). Activated carbon is the most common adsorbent for the removal of many organic contaminants. Commercial activated carbons are expensive and therefore, there is a need to search for effective adsorbents for 
economical wastewater treatment. Utilising wastes and biowastes of the environment as adsorbents for the removal of dyes from wastewater is of interest. Different materials such as coconut coir, bagasse pith, rice husk, neem tree leaves and orange peel have been used to prepare carbon from agricultural wastes as low-cost adsorbent materials for the removal of dyes from wastewater (bamboo-based activated carbon) Hameed, Ahmad, and Aziz 2007; activated palm ash (Hameed, Din, and Ahmad 2007a); palm shell (Adinata, Wan Daud, and Aroua 2007); durian peel (Hameed and Hakimi 2008); ackee apple (Bello, Auta, and Ayodele 2013), guava leaf (Ojedokun and Bello 2017a), corn cob (Ojedokun and Bello 2017b).

In this study, Cocoa pod husk $(\mathrm{CPH})$, a nonconventional agricultural waste material, which forms over $70 \%(w / w)$ of the whole matured cocoa fruit, i.e. over $700 \mathrm{~kg}$ of waste per each ton of cocoa fruit, is a major by-product from cocoa industry but is currently under-utilised. In Nigeria, more than 1.5 million tons of $\mathrm{CPH}$ are wasted annually, and some of the $\mathrm{CPH}$ is used as organic fertilizer, soap making and animal feed production (Bello and Ahmad 2012). Disposal of agricultural wastes like Cocoa pod husk is a problem for the farmers, and dumping of Cocoa pod husks without scientific methodology of management is a source for mosquito growth (Chethana 2014). However, to further utilise this cheap and abundant agricultural waste, $\mathrm{CPH}$ was converted to activated carbon for the removal of Congo red (CR) dye from aqueous solution.

\section{Materials and methods}

\section{Adsorbate}

The adsorbate used in this study is Congo red (CR) dye. It is the sodium salt of benzidinediazo-bis-1-naphthylamine-4-sulfonic acid; molecular formula, $\mathrm{C}_{32} \mathrm{H}_{22} \mathrm{~N}_{6} \mathrm{Na}_{2} \mathrm{O}_{6} \mathrm{~S}_{2}$; molecular weight, $696.66 \mathrm{~g} / \mathrm{mol}$; CI number, $22120 ; \lambda_{\max }, 497 \mathrm{~nm}$. It is a secondary diazo dye. CR was obtained from M/s Merck, and its solution was prepared by dissolving accurately weighed the amount of dye in distilled water. Different concentrations (20-100 mg/L) were prepared by serial dilution with distilled water.

\section{Preparation of activated carbon from cocoa pod husk}

Cocoa pod husks were collected from cocoa farms in three locations within Ogbomoso metropolis $\left(8^{0} 07^{\prime} \mathrm{N}, 4^{0} 16^{\prime} \mathrm{E}\right)$ in south-western part of Nigeria where they were deposited as a waste agricultural product. They were thoroughly washed with distilled water to remove dust and other impurities and dried under the sun until constant weight was attained. Dried Cocoa pod husks were ground, sieved into different sizes and stored in an airtight plastic container and labelled as CPHR for further use. A carefully weighed $25.0 \pm 0.01$ g grounded cocoa pod husk was placed in a beaker containing $500 \mathrm{~cm}^{3}$ of $0.3 \mathrm{~mol} /$ $\mathrm{dm}^{3}$ ortho-phosphoric acid $\left(\mathrm{H}_{3} \mathrm{PO}_{4}\right)$. In the present study, we prepared ACs from $\mathrm{CPH}$ by activation with $\mathrm{H}_{3} \mathrm{PO}_{4}$, the optimum $\mathrm{CPH} / \mathrm{PA}$ weight/volume ratio allowing complete activation of $\mathrm{CPH}$ was evidenced when $25.0 \pm 0.01$ g grounded $\mathrm{CPH}$ impregnated with $500 \mathrm{~cm}^{3}$ of $0.3 \mathrm{~mol} / \mathrm{dm}^{3}$ ortho-phosphoric acid $\left(\mathrm{H}_{3} \mathrm{PO}_{4}\right)$. The best yield was obtained using this weigh/volume ratio. Alteration in the ratio of $\mathrm{CPH} / \mathrm{PA}$ did not produce good yield during pyrolysis (Fierro et al. 2005). Hence, this ratio was used for the acid activation. Ortho-phosphoric acid (PA), $\mathrm{H}_{3} \mathrm{PO}_{4}$ is a common activating agent whose use has been extensively reported for preparing activated carbons from agricultural products (Diao, Walawender, and Fan 2002; Girgis and El-Hendawy 2002; Vernersson et al. 2002; Guo and Lua 2003). PA promotes bond cleavage in the biopolymers and dehydration at low temperatures. This process results in extensive cross-linking that binds volatile matter into the carbon products, leading to increase in carbon yield. Benaddi et al. (1998) showed that the mechanism of PA activation of biomass feedstock occurs through various steps: cellulose de-polymerisation, biopolymer dehydration, formation of aromatic rings and elimination of phosphate groups. This produces activated carbon with good yields and high surface areas. Activation conditions thus depend on the nature of the precursor, i.e. on the relative amounts of cellulose, hemicelluloses, lignin and ashes.

The content of the beaker was thoroughly mixed and heated until it formed a paste. The paste was then transferred to an evaporating dish, which was placed in a furnace and heated at $300{ }^{\circ} \mathrm{C}$ for thirty minutes. This was allowed to cool and washed with distilled water to a $\mathrm{pH}$ of 6.78 , oven dried at $105^{\circ} \mathrm{C}$ for $4 \mathrm{~h}$ to constant weight. It was then ground to a powder with a $106 \mathrm{~nm}$ mesh to obtain a fine powdered fluted activated carbon, which was kept in airtight plastic container and labelled as CPHAA for further use.

\section{Characterisation of CPHAA}

\section{Fourier Transform Infrared}

Fourier transform infrared (FTIR) spectroscopic analysis was performed (FTIR-2000, Perkin Elmer). The FTIR spectra give information about the characteristic functional groups on the surface of the sample. The spectra were measured from 4000 to $400 \mathrm{~cm}^{-1}$. The surface morphology of the samples was examined using a scanning electron microscope (SEM; Model VPFESEM Supra $35 \mathrm{VP}$ ). Elemental analysis of both raw- and acid-activated cocoa pod husks were carried out by energy dispersive X-ray (EDX) to determine the component elements present in the samples.

\section{Batch equilibrium method}

Batch adsorption process of Congo red dye removal from its aqueous solution was carried out by agitating $0.1 \mathrm{~g}$ of CPHAA with $100 \mathrm{~mL}$ of various concentrations of CR dye solution in $250 \mathrm{~mL}$ conical flasks. This was done by setting the samples into a water bath shaker, and the samples were shaken for $5 \mathrm{~h}$ at 303,313 and $323 \mathrm{~K}$, respectively, until equilibrium was reached. About $10 \mathrm{~mL}$ of the supernatants was taken using a syringe and analysed using UV-visible spectrophotometer (model A Analyst 800; Perkin Elmer) at a wavelength of $497 \mathrm{~nm}$ to determine the amount of CR dye adsorbed on cocoa pod husk. The amount of CR dye removed was calculated using Equations (1).

$$
q_{e}=\frac{\left(C_{0}-C_{e}\right) V}{w}
$$

where $q_{e}$ is the amount of CR dye adsorbed, $C_{0}$ is the initial dye concentration, $C_{e}$ is the initial dye concentration at equilibrium, 
$V$ is the volume of adsorbate used $\left(\mathrm{dm}^{3}\right)$ and $\mathrm{W}$ is the weight of the adsorbent ( $\mathrm{g}$ ).

\section{Effect of initial $C R$ dye concentration, contact time and solution temperature}

In order to study the effect of initial dye concentration and contact time on CR dye uptake, $100 \mathrm{~mL}$ of CR dye solution with initial concentrations of $20-100 \mathrm{mg} / \mathrm{L}$ was prepared in a series of 250-mL Erlenmeyer flasks. An equal mass of $0.10 \mathrm{~g}$ of CPHAA was added to each flask, covered with glass stopper, and the flasks were placed in an isothermal water bath shaker (Model Protech, Malaysia) at $303 \mathrm{~K}$ and a rotation speed of $120 \mathrm{rpm}$ until equilibrium was reached. The effect of solution temperature on the $C R$ dye adsorption process was examined by varying the adsorption temperature to 303,313 and $323 \mathrm{~K}$ by adjusting the temperature controller of the water bath shaker.

\section{Batch kinetic studies}

For the batch kinetic studies, the same procedure was followed, but the aqueous samples were taken at preset time intervals. The concentrations of CR dye were similarly measured. The CR dye uptake at any time, $q_{t}(\mathrm{mg} / \mathrm{g})$, was similarly calculated.

\section{Results and discussion}

\section{Characterization of adsorbent}

\section{Energy Dispersive X-Ray}

Elemental analysis of CPHAA is shown in Table 2. Elemental analyses of the samples were carried out using energy dispersive $\mathrm{X}$-ray to determine the component of elements present. Tables 1 and 2 show the various elements present in CPHR and CPHAA samples, respectively. Table 2 shows the presence of $\mathrm{C}, \mathrm{O}, \mathrm{Mg}$ and $\mathrm{K}$; carbon has the highest percentage weight when compared with other elements present in the sample. The high percentage weight of carbon is an indication that cocoa pod husk is a good and suitable precursor for preparing activated carbon. It was also observed that there is an increase in the weight percentage of carbon content from 60.55 to $8053 \%$ and a decrease in oxygen content from 29.86 to $13.02 \%$ comparing CPHR and CPHAA. This was as a result of activation using $\mathrm{H}_{3} \mathrm{PO}_{4}$ and carbonisation at $300^{\circ} \mathrm{C}$ for thirty minutes (Tables 1 and 2 ).

\section{Scanning Electron Micrograph}

Scanning electron micrograph (SEM) of CPHR and CPHAA is shown in Figures 1(a) and (b), respectively. From these figures, it is clear that CPHR surface was rough and the pores were not properly developed, whereas, in Figure 1(b), there are several pores formed on the CPHAA. This shows that $\mathrm{H}_{3} \mathrm{PO}_{4}$ was

Table 1. Energy dispersive X-ray percentage elemental composition of CPHR

\begin{tabular}{lrrrccc}
\hline Elem & Wt \% & At \% & K-Ratio & Z & A & F \\
\hline C & 60.55 & 70.38 & 0.3987 & 1.0139 & 0.6494 & 1.0002 \\
O & 29.86 & 26.06 & 0.0575 & 0.9970 & 0.1930 & 1.0000 \\
Mg & 0.64 & 0.37 & 0.0040 & 0.9570 & 0.6431 & 1.0006 \\
K & 8.95 & 3.19 & 0.0827 & 0.9040 & 1.0231 & 1.0000 \\
Total & 100.00 & 100.00 & & & & \\
\hline
\end{tabular}

effective in creating well-developed pores on the surface of the precursor, thus, leading to activated carbon with large surface area and porous surface structure. These pores provided a good surface for CR dye to be trapped and adsorbed (Amin 2008a, 2008b).

\section{FTIR analyses}

Table 3 shows the spectra of both raw- and acid-activated cocoa pod husk. In Table 3 (CPHR), the band at $3253 \mathrm{~cm}^{-1}$ is assigned to $\mathrm{O}-\mathrm{H}$ stretching of alcohol or carboxylic group, and that at $2919 \mathrm{~cm}^{-1}$ is assigned to $\mathrm{C}-\mathrm{H}$ stretching of an alkane. A sharp absorption at $1603 \mathrm{~cm}^{-1}$ is assigned to $\mathrm{C}=\mathrm{C}$ stretching of aromatic, and a broad absorption at $1375 \mathrm{~cm}^{-1}$ is assigned to $\mathrm{C}-\mathrm{H}$ bending of an alkane. A sharp prominent absorption at $1023 \mathrm{~cm}^{-1}$ is also assigned to $\mathrm{C}-\mathrm{O}$ stretching vibration of ether. In the CPHAA spectrum, some of the functional groups have shifted to lower wave number $(\mathrm{O}-\mathrm{H}$ stretching of alcohol, $\mathrm{C}-\mathrm{H}$ stretching of alkane and $\mathrm{C}=\mathrm{C}$ stretching of aromatic) or higher wave number $(\mathrm{C}-\mathrm{H}$ bending of alkane and $\mathrm{C}-\mathrm{O}$ stretching vibration of ether). These are due to the result of high temperature in activation process that broke some intermolecular bonds, i.e. forces holding molecules together (Gong et al. 2005; Tan, Ahmad, and Hameed 2008). The changes in spectra confirm the effect of the acid activation resulting in a reduction, broadening, disappearance or appearance of new peaks after acid activation (Figures 2 and 3).

\section{Effect of contact time initial CR dye concentration and solution temperature}

\section{Effect of contact time}

The effect of contact time on CR dye adsorption onto CPHAA at different concentrations is shown in Figure 4. The particle size of the sample used is $106 \mathrm{~nm}$. CR dye adsorption increases as the initial concentration increases. Figure 4 shows that the adsorption of CR dye was in two phases: (1) an initial rapid phase in which adsorption capacity increased sharply within the first 150 min due to rapid surface adsorption (external surface adsorption) and (2) a slower phase whose contribution to the total amount of dye adsorption was relatively small (internal surface adsorption) (Rais and Rajeev 2010). Adsorption equilibrium was achieved within $240 \mathrm{~min}$, after which the amount of dye adsorption becomes negligible. At the beginning, the adsorption rate was fast as the dye ions were adsorbed by the external surface of the activated carbons. When the adsorptions of the external surface reached saturation, the dye molecules are trapped in the pores of the adsorbent particles and were adsorbed by the internal surface of the particle. This phenomenon takes a relatively long contact time. (Chang and Juang 2005; Mall et al. 2005).

Table 2. Energy dispersive X-ray percentage elemental composition of CPHAA.

\begin{tabular}{lrrrccc}
\hline Elem & Wt \% & At \% & K-Ratio & Z & A & F \\
\hline $\mathrm{C}$ & 80.53 & 86.81 & 0.4156 & 1.0074 & 0.5122 & 1.001 \\
$\mathrm{O}$ & 13.02 & 10.54 & 0.0222 & 0.9906 & 0.1720 & 1.0000 \\
$\mathrm{Al}$ & 0.34 & 0.16 & 0.0026 & 0.9232 & 0.8445 & 1.0028 \\
$\mathrm{Si}$ & 0.56 & 0.26 & 0.0049 & 0.9503 & 0.9235 & 1.0046 \\
$\mathrm{P}$ & 4.69 & 1.96 & 0.0414 & 0.9113 & 0.9697 & 1.0004 \\
Ca & 0.86 & 0.28 & 0.0081 & 0.9193 & 1.0207 & 1.0000 \\
Total & 100.00 & 100.00 & & & & \\
\hline
\end{tabular}


(a)

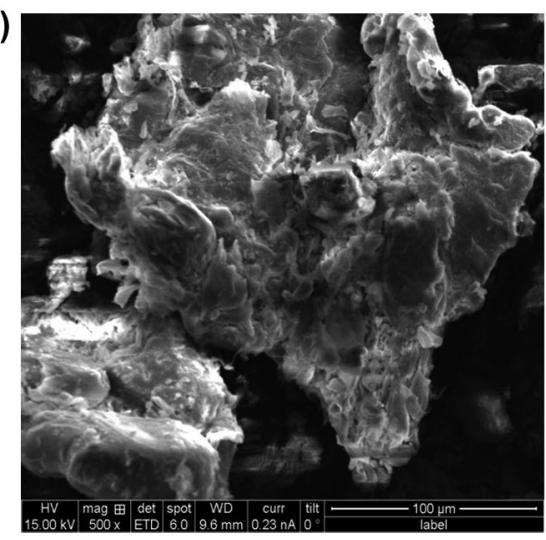

(b)

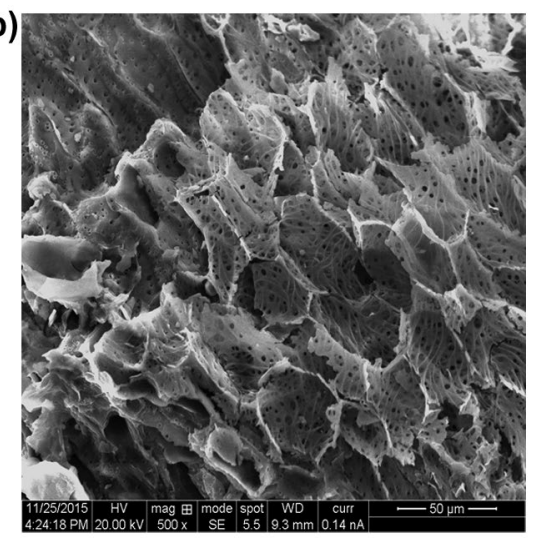

Figure 1. SEM micrographs of (a) CPHR (magnification $=500 \times$ ) and $(b)$ CPHAA (magnification $=500 \times$ ).

Table 3. FTIR spectra characteristics of raw and acid activated Cocoa pod husk $(\mathrm{CPH})$.

\begin{tabular}{|c|c|c|c|c|}
\hline \multirow[b]{2}{*}{ I.R Peaks } & \multicolumn{3}{|c|}{ Wave numbers $\left(\mathrm{cm}^{-1}\right)$} & \multirow{2}{*}{$\begin{array}{l}\text { Band assign- } \\
\text { ments }\end{array}$} \\
\hline & CPHR & CPHAA & Differences & \\
\hline 1 & 3253 & 3238 & -15 & $\begin{array}{l}\text { O-H stretching } \\
\text { vibration of } \\
\text { alcohol or car- } \\
\text { boxylic acid }\end{array}$ \\
\hline 2 & 2919 & 2910 & -9 & $\begin{array}{l}\mathrm{C}-\mathrm{H} \text { stretching of } \\
\text { alkane }\end{array}$ \\
\hline 3 & 1603 & 1602 & -1 & $\begin{array}{c}\mathrm{C}=\mathrm{C} \text { stretching } \\
\quad \text { vibration of } \\
\text { aromatic }\end{array}$ \\
\hline 4 & 1375 & 1436 & +61 & $\begin{array}{l}\mathrm{C}-\mathrm{H} \text { bending of } \\
\text { alkane }\end{array}$ \\
\hline 5 & 1023 & 1073 & +50 & $\begin{array}{l}\text { C-O stretching } \\
\text { vibration of } \\
\text { ether }\end{array}$ \\
\hline
\end{tabular}

\section{Effect of initial $C R$ dye concentration}

Five different concentrations, 20, 40, 60, 80 and $100 \mathrm{mg} / \mathrm{L}$, were selected to investigate the effect of CR dye concentration on CPHAA and CPHR, respectively. As shown in Figure 4, with increasing initial dye concentrations from 20 to $100 \mathrm{mg} / \mathrm{L}$, the amount of dye adsorbed by CPHAA increases from 13.14 to $37.2 \mathrm{mg} / \mathrm{g}$. The amount of CR dye adsorbed is a function of the initial concentration of the adsorbate. The adsorption of CR dye is fast at the initial stage and then becomes slower near equilibrium. This is as a result of a large number of vacant surface sites that are available for adsorption during the initial stages, after some time, the remaining vacant surface sites are difficult to occupy because of repulsive forces between the CR dye adsorbed on the surface of CPHAA and the solution phase. It is evident that the adsorption process is highly dependent on the initial dye concentration of the solution.

\section{Solution temperature}

The increase in the equilibrium adsorption of CR dyes on CPHAA with temperature shown in Figure 5 revealed that higher temperature favours $\mathrm{CR}$ dye removal via adsorption onto CPHAA. As temperature increases, the mobility of dye molecules increases. Increased mobility of as a result of increased temperature results in higher CR dye adsorption (Alkan and Dogan 2003; Hameed, Ahmad, and Aziz 2007).

\section{Effect of $\mathrm{pH}$ on $\mathrm{CR}$ dye adsorption}

The $\mathrm{pH}$ of the aqueous solution is an important controlling parameter in the adsorption process (Jain and Sikarwar 2014). The effect of initial solution $\mathrm{pH}$ on the adsorption of $\mathrm{CR}$ from aqueous solution was investigated in the $\mathrm{pH}$ range between 3.0 and 9.0 (which was adjusted with $0.1 \mathrm{M} \mathrm{HCl}$ or $0.1 \mathrm{M} \mathrm{NaOH}$ ). As shown in Figure 6, when the $\mathrm{pH}$ was varied from 3 to 10, the percentage adsorption decreased from 96.4 to $28.2 \%$. The maximum adsorption of CR dye was observed at $\mathrm{pH} 3.0$ (96.4\%). At $\mathrm{pH} 3.0$, a significantly high electrostatic attraction exists between the positively charged surface of the adsorbent and anionic dye resulting in the higher amount of dye adsorbed. As the $\mathrm{pH}$ of the system increases, the number of negatively charged sites increases, and the number of positively charged sites decreases. A negatively charged surface site on the adsorbent does not favour the adsorption of the dye anions due to the electrostatic repulsion. Similarly, lower adsorption at higher $\mathrm{pH}$ may be due to the abundance of $\mathrm{OH}^{-}$ions, causing ionic repulsion between the negatively charged surface and the anionic dye molecules. Therefore, there are no more exchangeable ions on the outer surface of the adsorbent at higher $\mathrm{pH}$ due to increase the number of negatively charged sites. This brings about electrostatic repulsion; consequently, there is a decrease in percentage dye adsorption (28.2\%). Similar trends were reported for the adsorption of the dye using different adsorbents (Vijayakumar et al. 2009; Torkian et al. 2012; Munagapati and Kim 2016).

\section{Kinetics of $C R$ dye adsorption}

\section{Pseudo-first-order kinetic model}

The model assumes that the rate of change the adsorption of solute with time is proportional to the difference in saturation concentration and the amount of solid uptake with time (Lagergren and Svenska 1898). It is generally expressed as:

$$
\ln \left(q_{e}-q_{t}\right)=\ln q_{e}-k_{1} t
$$

The values of $k_{1}$ and $q_{e}$ can be obtained from the slope and intercept of the linear plot of $\ln \left(q_{e}-q_{t}\right)$ vs. $t$. 


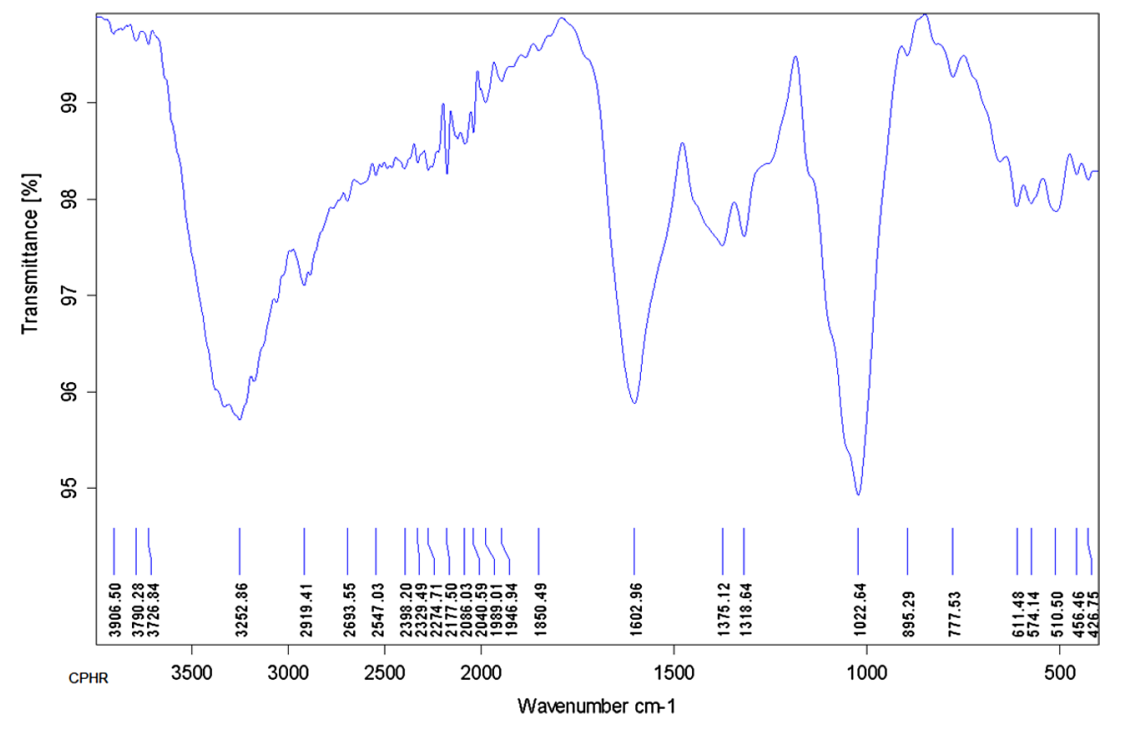

Figure 2. FTIR of spectrum CPHR.

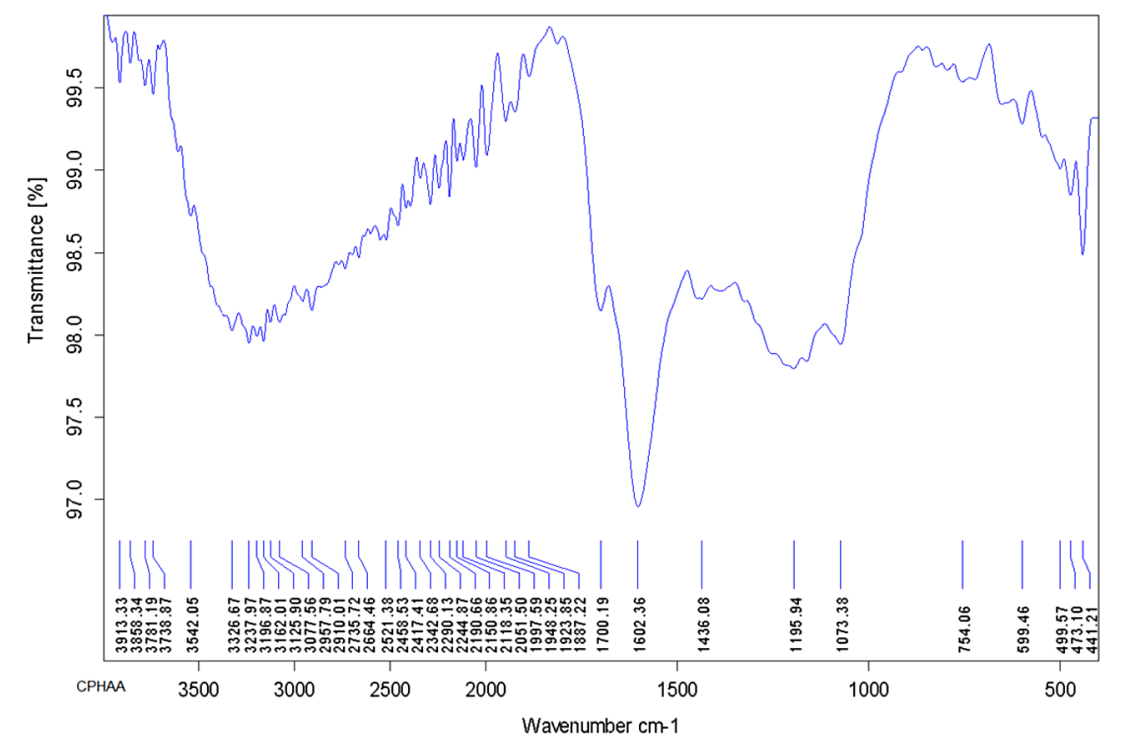

Figure 3. FTIR spectrum of CPHAA.

Pseudo-second-order kinetic model

The pseudo-second-order kinetic model (Ho and McKay 1999) is based on the adsorption capacity onto a solid phase. It is expressed as:

$$
\frac{t}{q_{t}}=\frac{1}{K_{2} q_{e}^{2}}+\frac{1}{q_{e}} t
$$

The slope and intercept of the plot of $t / q_{\mathrm{t}}$ vs. $t$ give the values of $q_{e}$ and $k_{2}$, respectively.

The pseudo-first-order kinetic model was used to test the adsorption data. A plot of $\ln \left(q_{e}-q_{t}\right)$ against $t$ at various concentrations and temperatures resulted in linear graphs with negative slopes (figure not shown). $k_{1}$ and $q_{e}$ are calculated from the slopes and intercepts, respectively. The pseudo-second-order equation was also used to test the adsorption data. Plots of $t / q_{t}$ vs. $t$ gave linear graphs from which $q_{e}$ and $k_{2}$ were estimated from the slopes and intercepts of the plot (Figure 7) for temperatures ranging from 303 to $333 \mathrm{~K}$. The values of the regression coefficient calculated (Table 4) from the second-order kinetic plots show that it has the highest $R^{2}$ value, best fitted with the experimental data and can be used to describe the adsorption of CR dye onto CPHAA.

\section{The Elovich model}

The Elovich equation is suitable in describing the kinetics of adsorption on heterogeneous solids. The Elovich model (Aharoni and Ungarish 1976) is expressed by Equation (4):

$$
q_{t}=\left(\frac{1}{\beta}\right) \ln (\alpha \beta)+\frac{1}{\beta} \ln t
$$

where $\alpha$ is the initial sorption rate $(\mathrm{mg} / \mathrm{g} \min ), \beta$ is the extent of surface coverage and activation energy for chemisorption ( $\mathrm{g} /$ $\mathrm{mg}$ ), The slope and intercept of the plot of $q_{t} \mathrm{vs}$. $\ln t$ can be used 


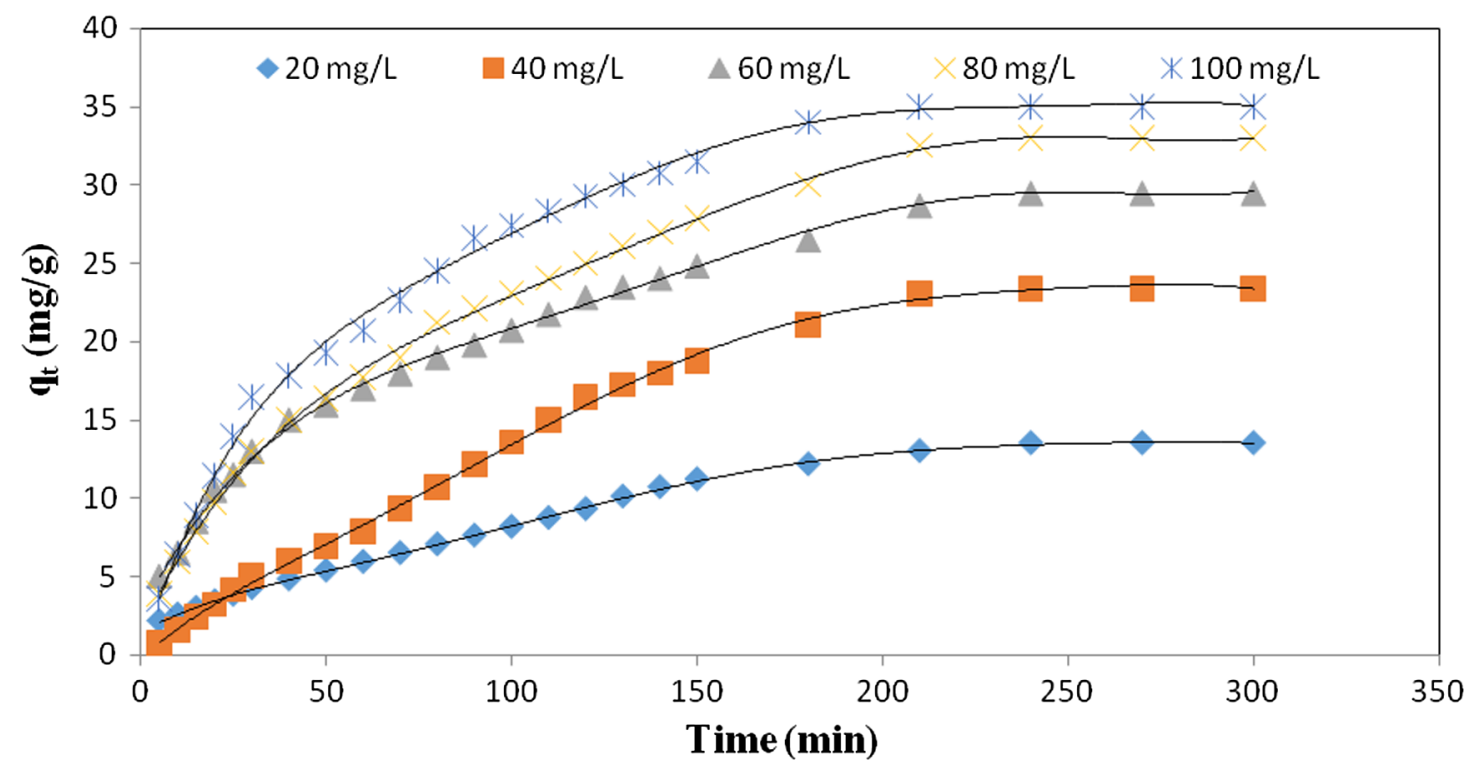

Figure 4. Effect of initial dye concentration on the adsorption of $C R$ dye by $C P H A A$ at $50^{\circ} \mathrm{C}$.

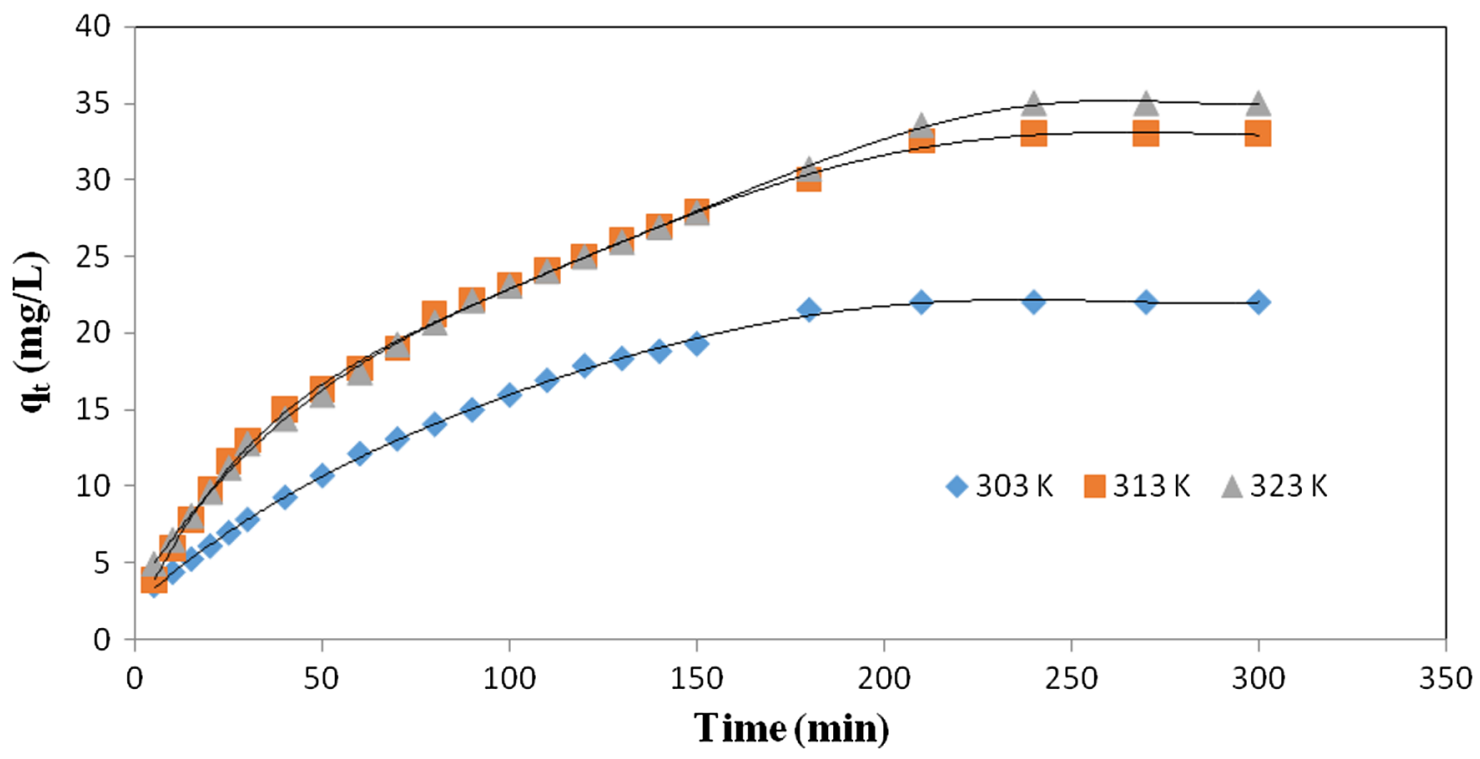

Figure 5. Effect of solution temperature on the adsorption of $100 \mathrm{mg} / \mathrm{L}$ CR dye onto CPHAA.

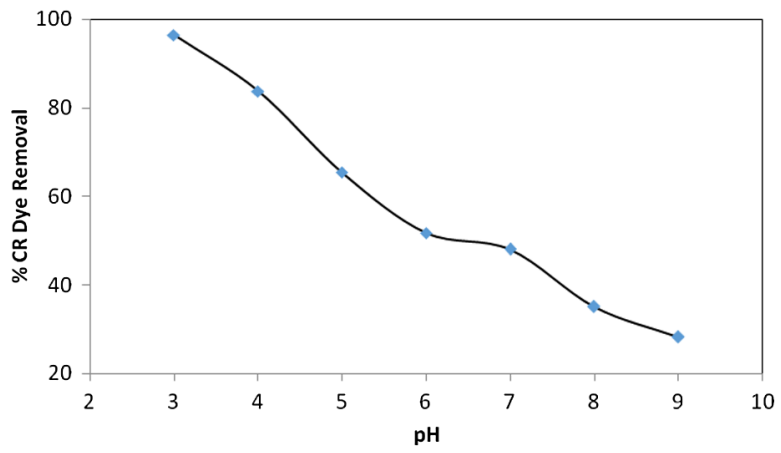

Figure 6. Percentage of $\mathrm{CR}$ dye adsorbed at different $\mathrm{pH}$. to calculate the values of the constants $\alpha$ and $\beta$, respectively. Adsorption data were also tested using Elovich model (plot of $q_{t}$ vs. $\ln t$ ) yields a linear relationship with a slope of $1 / \beta$ and intercept of $(1 / \beta) \ln (\alpha \beta)$ (figure not shown). The slope and intercept were used to calculate the values of the constants $\alpha$ and $\beta$ as shown in Table 4 . There was increased in initial adsorption rate $\alpha$ and decreased in desorption constant $\beta$ with an increase in initial dye concentration. A similar result was reported by Bello and Ahmad (2012).

Intraparticle diffusion model

In order to gain insight into the mechanisms and rate controlling steps affecting the kinetics of adsorption, the kinetic experimental 


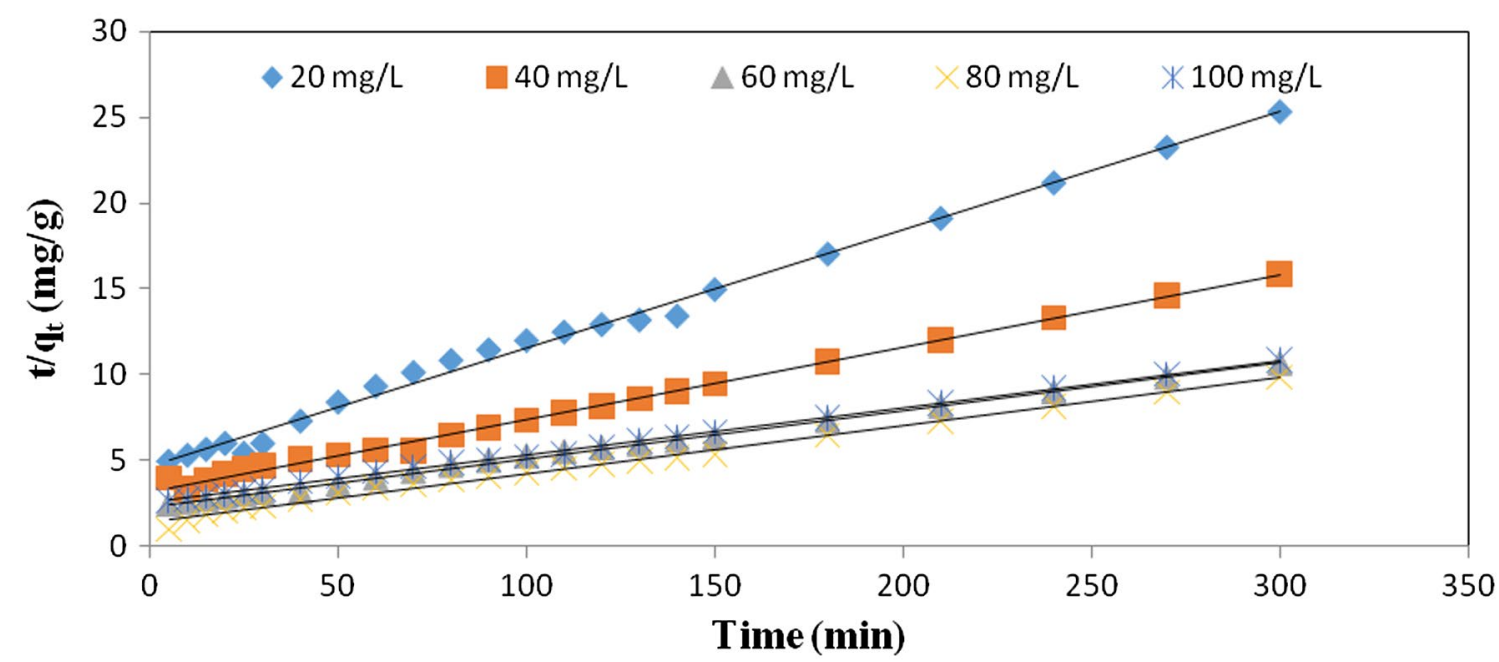

Figure 7. Plot of pseudo-second-order kinetic model for $\mathrm{CR}$ dye adsorption onto CPHAA at $50^{\circ} \mathrm{C}$.

Table 4. Parameters of different kinetic models of $\mathrm{CR}$ dye adsorption onto CPHAA at $50^{\circ} \mathrm{C}$.

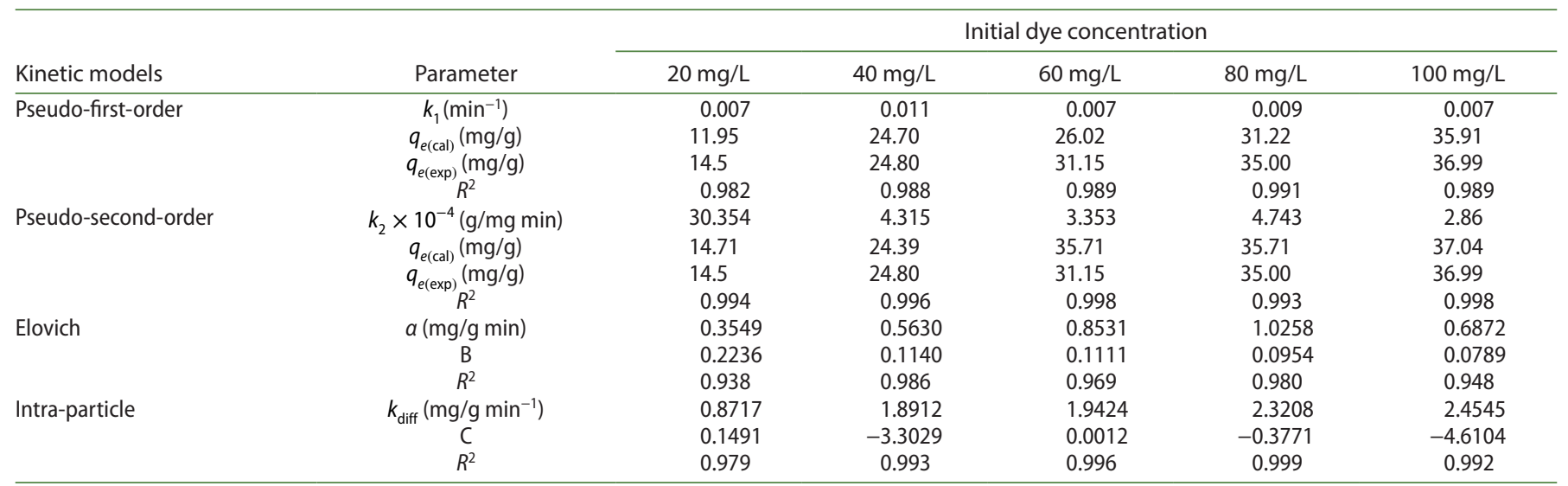

results were fitted to Weber's intraparticle diffusion (Weber and Morris 1963). It is expressed as:

$$
q_{t}=k_{\mathrm{diff}} t^{1 / 2}+C
$$

where $q_{t}$ is the amount of the adsorbate adsorbed at time t, $K_{\text {diff }}$ is the intraparticle diffusion rate constant $\left(\mathrm{mg} / \mathrm{g} \mathrm{min}^{1 / 2}\right), \mathrm{C}$ is the intercept. The kinetic results were analysed by the intraparticle model to elucidate the diffusion mechanism. The values of $q_{t}$ correlated linearly with the values of $t^{1 / 2}$ (Figure not shown), and the rate constant $k_{\text {diff }}$ was directly evaluated from the slope of the regression line. The intercept of the plot reflects the boundary layer effect. The larger the intercept, the greater the contribution of the surface sorption in the rate controlling step. The calculated intraparticle diffusion coefficient $k_{\text {diff }}$ values are listed in Table 4. If the regression of $q_{t}$ vs. $t^{1 / 2}$ is linear and passes through the origin, then intraparticle diffusion is the sole rate-limiting step. However, the linear plots at each concentration did not pass through the origin. This indicates that there is an initial boundary layer resistance, and the intraparticle diffusion was not only a rate controlling step. The deviation from the origin or near saturation might also be due to the difference in the mass transfer rate in the initial and final stages of adsorption (Mohanty, Das, and Biswas 2005).

\section{Adsorption isotherms}

The Langmuir equation is valid for monolayer adsorption onto a completely homogenous surface with a finite number of identical sites and with the negligible interaction between adsorbed molecules. The linearised form of Langmuir adsorption model (Langmuir 1916) is expressed as

$$
\frac{C_{e}}{q_{e}}=\frac{C_{e}}{q_{o}}+\frac{1}{q_{o} K_{L}}
$$

where $\mathrm{C}_{\mathrm{e}}$ is the dye concentration in the solution at equilibrium $(\mathrm{mg} / \mathrm{L}), q_{e}$ is the dye concentration on the adsorbent at equilibrium $(\mathrm{mg} / \mathrm{g}), q_{o}$ is the monolayer adsorption capacity of adsorbent $(\mathrm{mg} / \mathrm{g})$ and $k_{L}$ is the Langmuir adsorption constant $\left(\mathrm{L} \mathrm{mg}^{-1}\right)$. A plot of $C_{e} / q_{e}$ vs. $C_{e}$ gave a straight line with a slope $1 / q_{0}$ and an intercept of $1 / q_{0} K_{L}$ (Figure $8 \mathrm{a}$ ). The $R^{2}$ values for the Langmuir isotherm, when compared with the Freundlich, Tempkin and other isotherms, indicate that the adsorption of CR dye onto CPHAA fits the Langmuir isotherm most. Values of $q_{o}$ and $K_{L}$ are calculated from linear plots (figure not shown) and reported in Table 5. Table 6 shows that CPHAA is a promising adsorbent for CR dye. The value of $q_{o}$ obtained was compared 


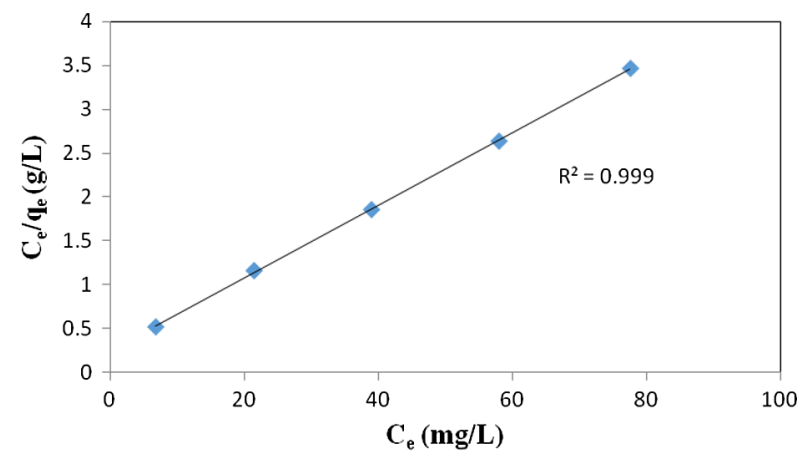

Figure 8a. Langmuir isotherm plot for the adsorption of $\mathrm{CR}$ dye on $\mathrm{CPHAA}$ at $50^{\circ} \mathrm{C}$.

Table 5. Isotherm model statistical parameters for the adsorption of CR dye onto CPHAA at different temperatures.

\begin{tabular}{lccc}
\hline & \multicolumn{3}{c}{ Temperature $(\mathrm{K})$} \\
\cline { 2 - 4 } Models & 303 & 313 & 323 \\
\hline Langmuir isotherm & & & \\
$q_{0}(\mathrm{mg} / \mathrm{g})$ & 24.21 & 42.55 & 43.67 \\
$R_{L}$ & 0.057 & 0.120 & 0.102 \\
$K_{L}(\mathrm{~L} / \mathrm{mg})$ & 0.073 & 0.110 & 0.165 \\
$R^{2}$ & 0.9998 & 0.9999 & 0.9999 \\
Freundlich isotherm & & & \\
$K_{F}(\mathrm{mg} / \mathrm{g})$ & & & \\
$n$ & 8.835 & 6.654 & 7.986 \\
$R^{2}$ & 4.441 & 2.402 & 2.579 \\
Temkin isotherm & 0.96 & 0.96 & 0.97 \\
$K_{T}(\mathrm{~mol} / \mathrm{g})$ & & & \\
$b_{T}(\mathrm{~mol} / \mathrm{kJ})$ & 0.587 & 0.675 & 0.892 \\
$R^{2}$ & 0.641 & 0.274 & 0.286 \\
$\mathrm{D}-\mathrm{R}$ isotherm & 0.979 & 0.994 & 0.995 \\
$q_{o}(\mathrm{mg} / \mathrm{g})$ & & & \\
$\beta$ & $\left.(\mathrm{mol} / \mathrm{KJ})^{2}\right)$ & 31.79 & 33.30 \\
$R^{2}$ & 21.41 & 6.367 & 4.252 \\
$E_{a}(\mathrm{~kJ} / \mathrm{mol})$ & 4.2312 & 0.930 & 0.918 \\
\hline
\end{tabular}

Table 6. Comparison of the maximum monolayer adsorption capacities of CR dye onto various adsorbents.

\begin{tabular}{lcl}
\hline Adsorbent & $q_{0}(\mathrm{mg} / \mathrm{g})$ & \multicolumn{1}{c}{ References } \\
\hline $\begin{array}{l}\text { Activated carbon (laboratory } \\
\text { grade) }\end{array}$ & 1.88 & Mall et al. (2005) \\
$\begin{array}{l}\text { Aspergilius niger biomass } \\
\text { Bagasse fly ash }\end{array}$ & 8.19 & $\begin{array}{l}\text { Fu and Viraraghavan (2002) } \\
\text { Coir pith }\end{array}$ \\
$\begin{array}{l}\text { Nall et al. (2005) } \\
\text { Neem leaf powder }\end{array}$ & 6.70 & $\begin{array}{l}\text { Namasivayam and Kavitha } \\
(2002)\end{array}$ \\
$\begin{array}{l}\text { Acid-activated red mud } \\
\text { Aniline propysilica xerogel }\end{array}$ & 41.20 & $\begin{array}{l}\text { Bhattacharyya and Sharma } \\
(2004)\end{array}$ \\
$\begin{array}{l}\text { 4-Vinyl pyridine grafted } \\
\text { poly(ethylene) terephthalate } \\
\text { fibres }\end{array}$ & 22.62 & $\begin{array}{l}\text { Tor and Cengeloglu (2006) } \\
\text { Pavan et al. (2008) }\end{array}$ \\
$\begin{array}{l}\text { Cashew nut shell } \\
\text { Montmorillonite }\end{array}$ & 18.1 & Arslan (2010) \\
Cocoa pod husk acid activated & & \\
\hline
\end{tabular}

with values for other adsorbents (Table 6). Table 6 compares the maximum monolayer coverage of CR dye unto different adsorbents. The reason why the value obtained for CPHAA is higher than others is inherent in the porosity and the surface area of the adsorbent. The pores are well developed (Figure 1(b)), resulting in increased surface area which enhances higher adsorption.
The essential characteristics of the Langmuir isotherm can be expressed by a dimensionless constant, $R_{L}$ called equilibrium parameter. The nature of the adsorption process could be unfavourable $\left(R_{L}>1\right)$, linear $\left(R_{L}=1\right)$, favourable $\left(0<R_{L}<1\right)$ or irreversible $\left(R_{L}=0\right)$. The $R_{L}$ values obtained here are listed in Table 5. The fact that all the $R_{L}$ values for the adsorption of CR onto CPHAA are in the range $0.057-0.120$ shows that the adsorption process is favourable. A similar result was obtained for the adsorption of CR dye onto ackee apple seed (Bello, Auta, and Ayodele 2013).

The linearised form of Freundlich model is expressed as (Freundlich 1906).

$$
\log q_{e}=\log k_{f}+\frac{1}{n} \log C_{e}
$$

where $q_{e}$ is the amount of dye adsorbed at equilibrium $(\mathrm{mg} / \mathrm{g})$, $\mathrm{C}_{e}$ is the equilibrium concentration of the adsorbate $(\mathrm{mg} / \mathrm{L})$, $k_{f}$ and $\mathrm{n}$ are constants incorporating the factors affecting the adsorption capacity and the degree of nonlinearity between the solute concentration in the solution and the amount adsorbed at equilibrium, respectively. Plots of $\log q_{e}$ vs. $\log C_{e}$ gave linear graphs (Figure $8 \mathrm{~b}$ ) with high $R^{2}$ values. Comparing the $R^{2}$ values with those obtained from Langmuir isotherms, the adsorption data do not fits the Freundlich isotherm well (Table 5). Values of $k_{f}$ and $n$ obtained from the slopes and intercepts of the graph reported in Table 5 shows the different isotherm parameters, as well the possibility of multilayer adsorption of CR dye through the percolation process; values of $n>1$ indicate that the adsorption is favourable.

The Temkin isotherm model has been developed on the concept of chemisorption. It assumes that the heat of adsorption of the molecules of the adsorbate linearly decreases with adsorbent layer coverage due to adsorbate-adsorbent interactions. The Temkin model (Temkin and Pyzhev 1940) is expressed as:

$$
q_{e}=B\left(\ln K_{T} C_{e}\right)
$$

This can then be further rearranged to:

$$
q_{e}=B \ln K_{T}+B \ln C_{e}
$$

where $q_{e}$ is the amount of adsorbate adsorbed at equilibrium $(\mathrm{mg} / \mathrm{g}), B=\mathrm{RT} / b_{T}=$ constant related to the heat capacity $(\mathrm{L} / \mathrm{mg})$, $R$ is the universal gas constant $(8.314 \mathrm{~J} / \mathrm{mol} \mathrm{K}), T$ is the absolute temperature $(\mathrm{K}), K_{T}$ is the equilibrium binding constant $(\mathrm{L} / \mathrm{mg})$, $C_{e}$ is the equilibrium concentration of adsorbate $(\mathrm{mg} / \mathrm{L})$.

A plot of $q_{e}$ vs. $\ln C_{e}$ for the Temkin isotherm yields a linear graphs (Figure 8c). The constants $K_{T}$ and $b_{T}$ are shown in Table 5. $K_{T}$ increase as the temperature increases, inferring that the adsorbate interaction with adsorbent increased with increasing temperature, hence, a higher rate of sorption was observed as energy increases. A similar trend was reported by Bello and Ahmad (2012).

The Dubinin-Radushkevich (Dubinin and Radushkevich 1947) is expressed as:

$$
q_{e}=q_{o} \exp \left(-B \varepsilon^{2}\right)
$$

where

$$
\varepsilon=\mathrm{RT} \ln \left(1+1 / C_{e}\right)
$$




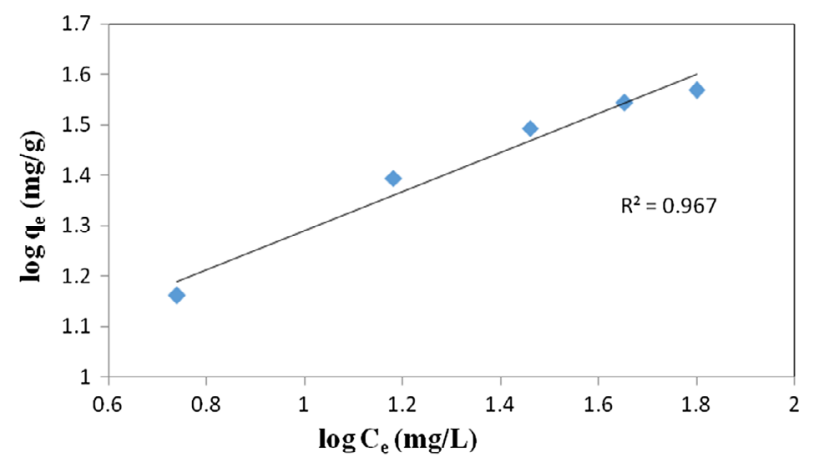

Figure 8b. Freundlich isotherm plot for the adsorption of CR dye on CPHAA at $50^{\circ} \mathrm{C}$.

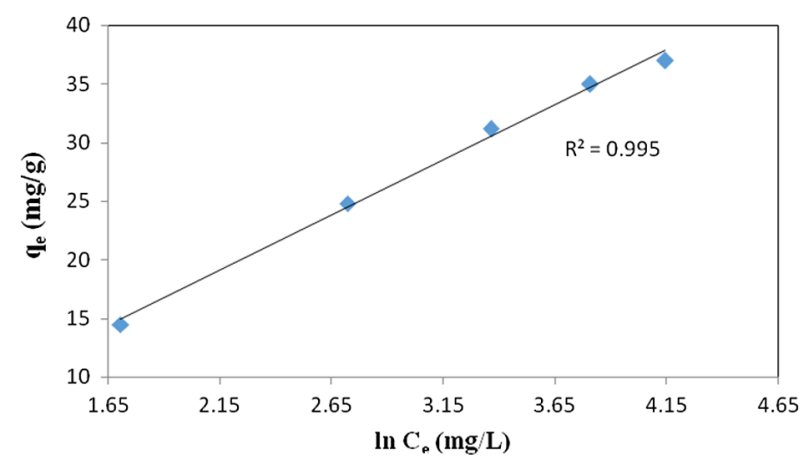

Figure 8c. Temkin isotherm plot for the adsorption of CR dye on CPHAA at $50^{\circ} \mathrm{C}$.

where $q_{e}$ is the amount of adsorbate adsorbed at equilibrium, $q_{o}$ is the maximum adsorption capacity, $B$ is the DubininRadushkevich constant, $R$ is the universal gas constant, $T$ is the absolute solution temperature, $C_{e}$ is the equilibrium concentration of adsorbate. Therefore, a plot of $\ln q_{e}$ against $\sum^{2}$ will give a straight line with slope of $\mathrm{B}$ and intercept of $\ln q_{0}$ (Figure $8 \mathrm{~d}$ ). Also, from the value of $B$, the free energy of sorption per molecule of the adsorbate, $E_{a}$, can be determined by using the equation:

$$
E_{a}=\frac{1}{\sqrt{2 B}}
$$

The adsorption energy $E_{a}$ helps in determining the nature of adsorption. The adsorption is physical if $E_{a}$ ranges from 1 to $8 \mathrm{~kJ} / \mathrm{mol}$. If the value of $E_{a}$ ranged between 9 and $16 \mathrm{~kJ} / \mathrm{mol}$, it is

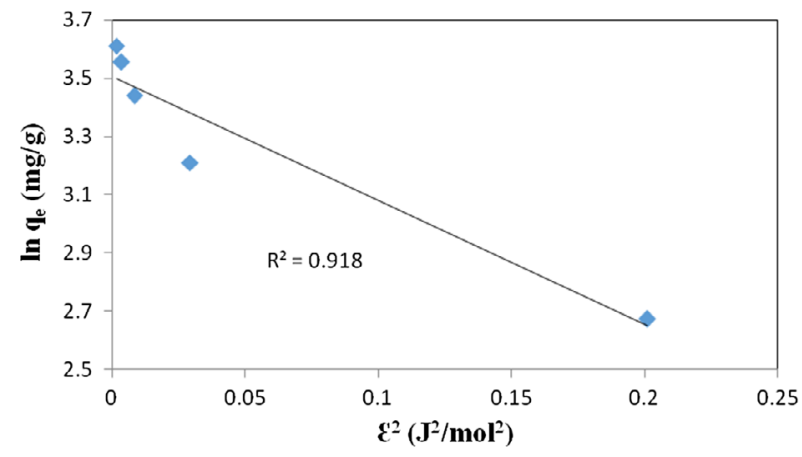

Figure 8d. D-R isotherm plot for the adsorption of CR dye on CPHAA at $50^{\circ} \mathrm{C}$. chemical adsorption. As presented in Table 5, the value of $E_{a}$ lies in the range $0.18-0.34 \mathrm{~kJ} / \mathrm{mol}$. Since $E_{a}<8 \mathrm{~kJ} / \mathrm{mol}$, it suggests that the adsorption mechanism is physical in nature (Onyango et al. 2004).

\section{Adsorption thermodynamics}

Thermodynamic parameters are used to reveal the energy changes that occur in an adsorption process. In order to investigate the adsorption process, three thermodynamic parameters were evaluated. They include: standard enthalpy change $\left(\Delta \mathrm{H}^{\circ}\right)$, standard entropy change $\left(\Delta S^{\circ}\right)$ and standard free energy change $\left(\Delta G^{\circ}\right)$. These values can be calculated by using Equation (13):

$$
\ln K_{L}=\frac{\Delta S^{o}}{R}-\frac{\Delta H^{o}}{R T}
$$

where $K_{L}$ is the Langmuir adsorption constant (L/mg), $\Delta S^{\circ}$ is the change in standard entropy $(\mathrm{kJ} / \mathrm{mol} \mathrm{K}), R$ is the universal gas constant $(8.314 \mathrm{~J} / \mathrm{mol} \mathrm{K}), \Delta H^{\circ}$ is the change in standard enthalpy $(\mathrm{kJ} / \mathrm{mol} \mathrm{K}), \mathrm{T}$ is the absolute temperature $(\mathrm{K})$. Hence, a plot of $\ln K_{L}$ against $1 / T$ yields the values of both $\Delta H^{\circ}$ and $\Delta S^{\circ}$ from the slope and intercept of the graph, respectively. Fundamentally, a positive $\Delta H^{\circ}$ value indicates that an adsorption process is endothermic in nature while a negative value represents exothermic reaction. A positive value of $\Delta S^{o}$ signifies an increase in randomness at the solid/solution interface that occurs in the adsorption process besides reflecting the affinity of the adsorbent towards the adsorbate. Furthermore, a negative $\Delta G^{\circ}$ value indicates that an adsorption process is a spontaneous process at the study temperature and vice-versa. $\Delta G^{\circ}$ can be calculated using the following relation:

$$
\Delta G^{o}=-\mathrm{RT} \ln K_{L}
$$

The calculated values of $\Delta H^{\circ}, \Delta S^{\circ}$ and $\Delta G^{\circ}$ are listed in Table 7 . The Van't Hoff plot (Equation (13)) for the adsorption of CR dye onto CPHAA gave linear graphs (Figure 9). As shown in Table 7, the negative values of $\Delta G^{\circ}$ indicated the feasibility of the process

Table 7. Thermodynamic parameters for the adsorption of CR dye adsorption onto CPHAA at different temperatures.

\begin{tabular}{lcccccc}
\hline Temp (K) & $K_{L}(\mathrm{~L} / \mathrm{mg})$ & $\begin{array}{c}K_{L} \times 10^{4} \\
(\mathrm{~L} / \mathrm{mol})\end{array}$ & $\begin{array}{c}\Delta G^{\circ} \\
(\mathrm{kJ} / \mathrm{mol})\end{array}$ & $\begin{array}{c}\Delta H_{a d s}^{o} \\
(\mathrm{~kJ} / \mathrm{mol})\end{array}$ & $\begin{array}{c}\Delta S^{\circ} \\
(\mathrm{kJ} / \mathrm{mol} \mathrm{K})\end{array}$ & $\begin{array}{c}E_{a} \\
(\mathrm{~kJ} / \mathrm{mol})\end{array}$ \\
\hline 303 & 0.073 & 5.09 & -27.30 & 33.57 & 0.20 & 36.09 \\
313 & 0.110 & 7.69 & -29.28 & & & 36.17 \\
323 & 0.165 & 11.5 & -31.29 & & & 36.26 \\
\hline
\end{tabular}

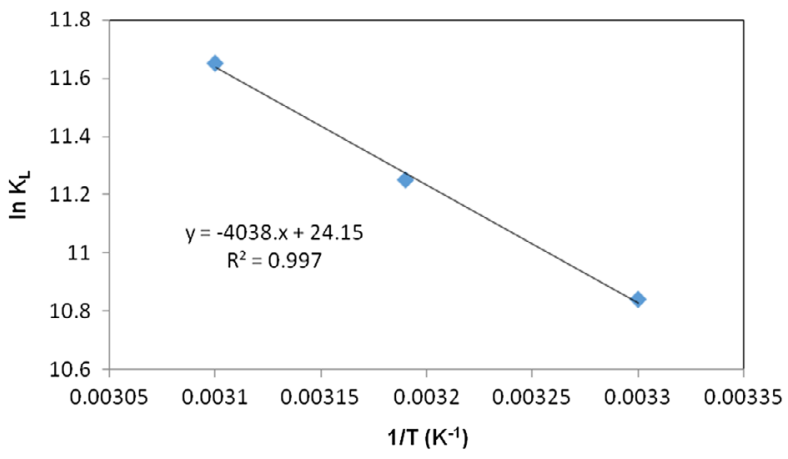

Figure 9. Van't Hoff plot of CR dye adsorption onto CPHAA. 
and the spontaneous nature of the adsorption with a high preference of CR dye onto the prepared activated carbon. Values of $\Delta H^{\circ}$ and $\Delta S^{\circ}$ were positive, showing that the adsorption process is endothermic and there was increased randomness between the adsorbent/adsorbate interfaces during the adsorption of $\mathrm{CR}$ dye onto CPHAA.

\section{Conclusions}

The present investigation shows that activated carbon prepared from cocoa pod husk was a promising adsorbent for the removal of Congo red dye from aqueous solutions over a wide range of concentrations. FTIR, SEM and EDX revealed the adsorptive features of this novel adsorbent. Equilibrium data were fitted to Langmuir, Freundlich, Temkin and Dubinin-Radushkevich isotherms, and the equilibrium data were best described by the Langmuir isotherm model, with maximum monolayer adsorption capacity of $43.67 \mathrm{mg} / \mathrm{g}$ at $50{ }^{\circ} \mathrm{C}$. The adsorption performance of the cocoa pod husk acid activated was comparable to the commercial activated carbon and some other adsorbents reported in earlier studies. The adsorption kinetics was found to follow closely the pseudo-second-order kinetic model. The negative value of free energy change indicated the spontaneous nature of sorption. The positive values of $\Delta H^{\circ}$ indicated that the adsorption process was endothermic in nature. The mean free energy obtained from $\mathrm{D}-\mathrm{R}$ isotherm showed that the adsorption process is physically controlled. Results from this study have shown that cocoa pod husk can be used as a low-cost, readily available and easily prepared sorbent for the effective removal of CR dye from aqueous solution.

\section{Disclosure statement}

No potential conflict of interest was reported by the authors.

\section{Funding}

The corresponding author acknowledges the support obtained from The World Academy of Science (TWAS) in form of research grants; research grant numbers: 11-249 RG/CHE/AF/AC_1_UNESCO FR: 3240262674 (2012) and 15-181 RG/CHE/AF/AC_1_: 3240287083 (2015), respectively.

\section{Notes on contributors}

MO Olakunle completed his B Tech degree with a First Class Honors in Pure and Applied Chemistry from Ladoke Akintola University of Technology, Ogbomoso, Oyo State, Nigeria in 2015. He is currently pursuing his MSc Degree in Department of Chemistry, University of Ibadan, Nigeria. He has published one (1) paper in international conference proceeding. His long term goal is to become an outstanding academic researcher and a seasoned consultant in leading manufacturing industries.

A A Inyinbor is a lecturer of Industrial Chemistry Programme, Physical Sciences Department of the College of Science and Engineering, Landmark University, Omu Aran, Kwara State, Nigeria. She obtained her PhD in Environmental/Analytical Chemistry from the prestigious University of Ilorin, Ilorin, Nigeria. Her passion for sustainable development and healthy living of her people continuously provides the drive into the search for effective adsorbent in lieu of the expensive activated carbon to mitigate pollution via recalcitrant dyes and heavy metals. Her research findings have been published in both local and international journals of high repute. She has published over twenty (20) publications in reputable journal outlets as well as leading conference proceedings. Her research focuses on environmental protection via effective wastewater treatment.

A O Dada is a Lecturer in Landmark University, Industrial Chemistry Programme, Department of Physical Sciences of the College of Science and Engineering. He completed his $\mathrm{PhD}$ in the Department of Chemistry, University of Ilorin in 2015. His research areas/interests are: adsorption, waste water treatment, dyes and heavy metal removal, nano-materials and their various applications, green synthesis of nano-materials and their antibacterial studies, photo catalysis and dye degradation. He is a member of two research clusters in his home institution and other accredited professional bodies. He was ranked 293rd position in Google scholar citation on the list of 600 scientists in Nigerian institutions in 2015 and constantly spotted by Research Gate as one of the researchers with good citation in Landmark University. He has published twenty eight (28) articles in peer-reviewed journals and he also functions as reviewer to some reputable journals. He is currently working on synthesis of novel nanocomposites and their applications in industrial effluent treatment.

O S Bello is Associate Professor of Physical Chemistry in the Department of Pure and Applied Chemistry, LAUTECH, Ogbomoso, Oyo State, Nigeria. He completed his PhD in Physical Chemistry at the University of Ibadan, Nigeria in 2008. He is a recipient of The World Academy of Science (TWAS) Awards, Fellowships and Research grants. In 2015, he was named as one of the 175 faces of Chemistry by the Royal Society of Chemistry in United Kingdom. In May 2016, he emerged winner of the 2016 edition of Prof. Kayode Adebowale Young Scientist Prize in Chemical Sciences Organised by Nigerian Young Academy. He has published over seventy (70) papers in reputable and peer reviewed local and international journals of high repute. He has twenty two (22) papers in proceedings of the leading national and international conferences. His research interest is focused on adsorption of dyes and heavy metals from wastewaters using agricultural waste materials as adsorbents in lieu of expensive commercial activated carbon to bio-remediate the environment.

\section{References}

Adinata, D., W. M. A. Wan Daud, and M. K. Aroua. 2007. "Preparation and Characterization of Activated Carbon from Palm Shell by Chemical Activation with $\mathrm{K}_{2} \mathrm{CO}_{3}$." Bioresource Technology 98: 145-149.

Aharoni, C., and M. Ungarish. 1976. "Kinetics of Activated Chemisorptions. Part I: The Non-Elovichian Part of the Isotherm." Journal of Chemical Society, Faraday Transaction 72: 265-268.

Aksu, Z. 2005. "Application of Biosorption for the Removal of Organic Pollutants: A Review." Process Biochemistry 40: 997-1026.

Alkan, M., and M. Dogan. 2003. "Adsorption Kinetics of Victoria Blue onto Perlite." Fresenius Environment Bulletin 12: 418-425.

Amin, N. K. 2008a. "Removal of Reactive Dye from Aqueous Solutions by Adsorption Onto Activated Carbons Prepared from Sugarcane Bagasse Pith." Desalination 223: 152-161.

Amin, N. K. 2008b. "Removal of Acid Blue-106 Dye from Aqueous Solution using New Activated Carbons Developed from Pomegranate Peel: Adsorption Equilibrium and Kinetics." Journal of Hazardous Materials 165: 52-62.

Arslan M. 2010. "Use of 1,6-diaminohexane-functionalized Glycidyl Methacrylateg- Poly (Ethylene Terephthalate). Fiber for Removal of Acidic Dye from Aqueous Solution." Fiber Polymer 11: 177-184.

Baban, A., A. Yediler, and N. K. Ciliz. 2010. "Integrated Water Management and CP Implementation for Wool and Textile Blend Processes." Clean Technologies and Environmental Policy 38: 84-90.

Bello, O.S., and M.A. Ahmad. 2012. "Adsorptive Removal of Synthetic Dye Using Cocoa Pod Husks.” Toxicological \& Environmental Chemistry 93 (7): 1298-1308.

Bello, O. S., M. Auta, and O. B. Ayodele. 2013. "Ackee Apple (Blighia sapida) Seeds: A Novel Adsorbent for the Removal of Congo Red Dye from Aqueous Solutions." Chemistry and Ecology 29 (1): 58-71.

Benaddi, H., D. Legras, J.N. Rouzaud, and F. Beguin. 1998. "Influence of the Atmosphere in the Chemical Activation of Wood by Phosphoric Acid." Carbon 36: 306-309. 
Bhattacharyya, K. G., and A. Sharma. 2004. "Azadirachta indica Leaf Powder as an Effective Biosorbent for Dyes: A Case Study with Aqueous Congo Red Solutions." Journal of Environmental Management 71: 217229.

Chang, M., and R. Juang. 2005. "Equilibrium and Kinetic Studies on the Adsorption of Surfactant, Organic Acids and Dyes from Water onto Natural Biopolymers." Colloids and Surfaces A: Physicochemical and Engineering Aspects 269: 35-46.

Chethana, P. 2014. "A Research on Cocoa Pod Husk Activated Carbon for Textile Industrial Wastewater Colour Removal.” International Journal of Research in Engineering and Technology 3: 731-737.

Ciardelli, G., L. Corsi, and M. Marucci. 2000. "Membrane Separation for Wastewater Reuse in the Textile Industry." Resource, Conservation and Recycling 31: 189-197.

DeoMall, I., V. C. Srivastava, N. K. Agarwal, and I. M. Mishra. 2005. "Removal of Congo Red from Aqueous Solution by Bagasse Fly Ash and Activated Carbon: Kinetic Study and Equilibrium Isotherm Analyses." Chemosphere 61: 492-501.

Diao, Y., W. P. Walawender, and L. T. Fan. 2002. "Activated Carbons Prepared from Phosphoric Acid Activation of Grain Sorghum." Bioresource Technology 81: 45-52.

Dubinin, M. M., and L. V. Radushkevich. 1947. "Equation of the Characteristic Curve of Activated Carbon." Proceeding of the Academy Science. Physical Chemistry Section USSR 55: 331-333.

Fierro, V., V. Torne-Fernandez, D. Montane, and A. Celzard. 2005. "Study of the Decomposition of Kraft Lignin Impregnated with Orthophosphoric Acid." Thermochimica Acta 433: 142-148.

Freundlich, H. M. F. 1906. "Over the Adsorption in Solution." Zeitschrift fur Physikalische Chemie (Leipzig) 57: 385-470.

$\mathrm{Fu}$ Y. Z., and T. Viraraghavan. 2002. "Removal of Congo Red from an Aqueous Solution by Fungus Aspergillus Niger." Advances in Environmental Research 7: 239-247.

Girgis, B. S., and A. A. El-Hendawy. 2002. "Porosity Development in Activated Carbons Obtained from Date Pits under Chemical Activation with Phosphoric Acid." Microporous and Mesoporous Materials 52: 105-117.

Gong, R., M. Li, C. Yang, Y. Sun, and J. Chen. 2005. "Removal of Cationic Dyes from Aqueous Solution by Adsorption on Peanut Hull." Journal of Hazardous Materials 121: 247-250.

Guo, J., and A. C. Lua. 2003. "Adsorption of Sulphur Dioxide onto Activated Carbon Prepared from Oil-palm Shells with and without Preimpregnation." Separation and Purification Technology 30 (3): 265-273.

Gurses, A., C. Dogar, M. Yalcin, M. Acikyildiz, R. Bayrak, and S. Karaca. 2006. "The Adsorption Kinetics of the Cationic Dye, Methylene Blue, onto Clay." Journal of Hazardous Materials 131: 217-228.

Hameed, B. H., and H. Hakimi. 2008. "Utilization of Durian (Durio zibethinus Murray) Peel as Low Cost Sorbent for the Removal of Acid Dye from Aqueous Solutions." Biochemical Engineering Journal 39: 338-343.

Hameed, B. H., A Din, and A. L. Ahmad. 2007a. "Adsorption of Methylene Blue onto Bamboo-based Activated Carbon: Kinetics and Equilibrium Studies." Journal of Hazardous Materials 141: 819-825.

Hameed, B. H., A. A. Ahmad, and N. Aziz. 2007. "Isotherms, Kinetics and Thermodynamics of Acid Dye Adsorption on Activated Palm Ash." Chemical Engineering Journal 133: 195-203.

Ho, Y., and G. McKay. 1999. “The Sorption of Lead(II) Ions on Peat.” Water Research. 33: 578-584.

Jain, R., and S. Sikarwar. 2014. "Adsorption and Desorption Studies of Congo Red Using Low-cost Adsorbent: Activated De-oiled Mustard." Desalination and Water Treatment 52: 7400-7411.

Kumar P. S., S. Ramalingam, C. Senthamarai, M. Niranjanaa, P. Vijayalakshmi, and S. Sivanesan. 2010. "Adsorption of Dye from Aqueous Solution by Cashew Nut Shell: Studies on Equilibrium Isotherm, Kinetics and Thermodynamics of Interactions." Desalination 261: 52-60

Lagergren, S., and B. K. Svenska. 1898. "On the Theory of So-called Adsorption of Materials." The Royal Swedish Academy of Science Documents 24: 1-13.

Langmuir, I. 1916. "The Constitution and Fundamental Properties of Solids and Liquids." Journal of the American Chemical Society 38: 2221-2295.
Mall, I. D., V. C. Srivastava, N. K. Agarwal, and I. M. Mishra. 2005. "Removal of Congo Red from Aqueous Solution by Bagasse Fly Ash and Activated Carbon: Kinetic Study and Equilibrium Isotherm Analyses." Chemosphere 61: 492-501.

Malik, P. K., and S. K. Saha. 2003. "Oxidation of Direct Dyes with Hydrogen Peroxide using Ferrous Ion as Catalyst." Separation and Purification Technology 31: 241-250.

Mishra, G., and M. Tripathy. 1993. "A Critical Review of the Treatment for Decolorization of Textile Effluent." Colourage Dyes 40: 35-38.

Mohanty, K., D. Das, and M. N. Biswas. 2005. "Adsorption of Phenol from Aqueous Solutions Using Activated Carbons Prepared from Tectona grandis Sawdust by $\mathrm{ZnCl}_{2}$ activation." Chemical Engineering Journal 115: $121-131$.

Munagapati, V. S., and D. Kim. 2016. "Adsorption of Anionic Azo Dye Congo Red from Aqueous Solution by Cationic Modified Orange Peel Powder." Journal of Molecular Liquids 220: 540-548.

Namasivayam C., and D. Kavitha. 2002. "Removal of Congo Red from Water by Adsorption onto Activated Carbon Prepared from Coir Pith, an Agricultural Solid Waste." Dyes and Pigments 54: 47-58.

Namasivayam, C., R. Radhika, and S. Suba. 2001. "Uptake of Dyes by a Promising Locally Available Agricultural Solid Waste: Coir Pith." Waste Management 21: 381-387.

Namasivayam, C., R. T. Yamuna, and J. Jayanthi. 2003. "Removal of Methylene Blue from Wastewater by Adsorption on Cellulose Waste, Orange Peel." Cellulose Chemistry and Technology 37: 333-339.

Ojedokun, A. T., and O. S. Bello. 2017a. "Kinetic Modeling of Liquidphase Adsorption of Congo Red Dye Using Guava Leaf-based Activated Carbon." Applied Water Science 7: 1965-1977. doi:10.1007/s13201-0150375-y.

Ojedokun, A. T., and O. S. Bello. 2017b. "Liquid Phase Adsorption of Congo Red Dye on Functionalized Corn Cobs." Journal of Dispersion Science Technology 38 (9): 1285-1294.

Onyango, M. S., Y. Kojima, O. Aoyi, E. C. Bernardo, and H. Matsuda. 2004. "Adsorption Equilibrium Modelling and Solution Chemistry Dependence of Fluoride Removal from Water by Trivalent-cationexchanged Zeolite." Journal of Colloid and Interface Science 279: 341350.

Panswed, J., and S. Wongehaisuwan. 1986. "Mechanism of Dye Wastewater Color Removal by Magnesium Carbonate-hydrated Basic." Water Science and Technology 18: 139-144.

Pavan F., S. Dias, E. Lima, and E. Benvenutti. 2008. "Removal of Congo Red from Aqueous Solution by Anilinepropylsilica Xerogel." Dyes and Pigments 76: 64-69.

Rais, A., and K. Rajeev. 2010. "Adsorptive Removal of Congo Red Dye from Aqueous Solution using Bael Shell Carbon." Journal of Applied Surface Science 257: 1628-1633.

Robinson, T., G. McMullan, R. Marchant, and P. Nigam. 2001. "Remediation of Dyes in Textile Effluent: A Critical Review on Current Treatment Technologies with a Proposed Alternative." Bioresource Technology 77: 247-255.

Seshadri, S., P. I. Bishop, and A. M. Agha. 1994. "Anaerobic/Aerobic Treatment of Selected Azo Dyes in Wastewater." Waste Management 14: 127-137.

Soloman, P. A., C. A. Basha, V. Ramamurthi, K. Koteeswaran, and N. Balasubramanian. 2009. "Electrochemical Degradation of Remazol Black B Dye Effluent." Clean Technologies and Environmental Policy 37: 889-900.

Tan, I. A. W., A. L. Ahmad, and B. H. Hameed. 2008. "Adsorption of Basic Dye using Activated Carbon Prepared from Oil Palm Shell: Batch and Fixed Bed Studies." Desalination 225: 13-28.

Temkin, M., and V. Pyzhev. 1940. "Kinetics of Ammonia Synthesis on Promoted Iron Catalysts." Acta Physiochimica. URSS 12 (3): 217-222.

Tor A., and Y. Cengeloglu. 2006. "Removal of Congo Red from Aqueous Solution by Adsorption onto Acid Activated Red Mud." Journal of Hazardous Materials 138: 409-415.

Torkian, L., B. G. Ashtiani, E. Amereh, and N. Mohammadi. 2012 "Adsorption of Congo Red onto Mesoporous Carbon Material: Equilibrium and Kinetic Studies." Desalination and Water Treatment 44: 118-127. 
Vernersson, T., P. R. Bonelli, E. G. Cerella, and A. L. Cukierman. 2002 "Arundo donax Cane as a Precursor for Activated Carbons Preparation by Phosphoric Acid Activation." Bioresource Technology 83: 95-104.

Vijayakumar, G., M. Dharmendirakumar, S. Renganathan, S. Sivanesan, G. Baskar, and K. P. Elango. 2009. "Removal of Congo Red from Aqueous Solutions by Perlite." CLEAN - Soil, Air, Water 37 (4-5): 355-364.

Vijayaraghavan K., S. W. Won, and Y. Yun. 2009. "Treatment of Complex Remazol Dye Effluent Using Sawdust and Coal-based Activated Carbons." Journal of Hazardous Materials 167: 790-796.
Wang, S., Y. Boyjoo, A. Choueib, and Z. H. Zhu. 2005. "Removal of Dyes from Aqueous Solution using Fly Ash and Red Mud." Water Research 39: $129-138$.

Wang L., and A. Wang. 2007. "Adsorption Characteristics of Congo Red onto the Chitosan/ Montmorillonite Nanocomposite." Journal of Hazardous Materials 147: 979-985.

Weber, W. J., and J. C. Morris. 1963. "Kinetics of Adsorption on Carbon from Solution." Journal of Sanitary Engineering Division ASCE 89: 3160 